\title{
台湾における皇民化運動
}

\author{
政策の形成と短歌の広がり \\ Yenhung LAI/頼衍宏: Associate Professor Department of Japanese Language and Literature, \\ Providence University) \\ 圂enko@hotmail.com \\ (台湾) 静宜大学日本語文学系副教授。比較文学。主著に『早本文学管見」(新北：尚昂文化 2015)、「法隆

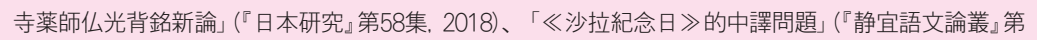 \\ 12-1号. 2019) など。
}

\section{The Kominka Movement in Taiwan \\ : Policy Formulation and the Spread of the Tanka}

It is generally believed that the Kominka movement in Taiwan started between the late 1930s and 1945. There have been numerous discussions of its origins and its significance, based on the historical records of the Governor's administration at that time. However, much has been overlooked in these debates, because the starting point of the movement has been misguidedly set too late, while its end point has been set too early. More importantly, generally the initial proponents of the movement have not been accurately identified. As a result, these discussions have brushed past some of the core dimensions of the movement, leading to the misconception that Komin literature consisted merely of Komin novels. This paper argues that for the purpose of setting the record straight, it is important to recognize the role of the tanka genre in the Kominka movement from the early 1930s to the postwar period.

Keywords Kamada Seii(鎌田正威), Epitaph(墓誌銘), Tsuchiya Yonekichi(土屋 米吉), Political Manipulation(政治利用), Honkadori(本歌取) 


\section{1 はじめに}

皇民化運動については、1930年代後半から1945年まで展開したとされている。それ を政策として採用した総督の施政年表に基づいて論じていく業績は枚挙に遑がない。し かし、見落としが生じがちである。なぜなら、その上限は遅きに失するし、下限も早 きに失する恐机があからである。重要なのは、その最初の主唱者が特定されないまま では、運動の核心を捉えられないということである。また、皇民文学は皇民小説だけか らなるという偏った認識も横行している。それを是正するためには、短歌ジャンルと いう新しい視点が有効である。ここでは、1930年代前半〜戦後にわたって展開した皇民 化運動と皇民短歌との実体を追跡してみたい。

\section{2「皇民」の起源}

日本の六国史における「皇民」の用例を検討する際に、いま重視すべきなのは、東北 地方の「夷虜」の「乱」を平定すべく、近隣する「皇民」の兵制を見直そうとする桓武天皇の 発した『続日本紀』延暦二年(783)六月辛亥条の勅であろう。

今聞、坂東諸国、属有軍役、毎多选弱、全不堪戦。(略)同曰皇民、豈合如此。宜仰 坂東八国、簡取所有散位子、郡司子弟、及浮宕等類、身堪軍士者、(略)専習用兵之 道、並備身装。

これを分析した森清人²によると、「明らかに国民皆兵の趣旨を宣はせられたもので ありましてわが兵制史上注目すべき詔勅であると信じます」と正しく位置づけられてい る。換言すれば、「皇民」発言の原点は皆兵制の予告だったのである。戦雲みなぎる 1931 〜 1945年の東アジア情勢を眺めると、「従来の「同化」政策と異なり、「皇民化」は異民族 である台湾人を「天皇の赤子」として、自らの戦争に動員することを最大の目的とした運 動であった」という星名宏修 ${ }^{3}$ 卓見を想起すれば、中央政府が外敵の圧力に晒されてい て、植民地側も何らかの形で動員に応じねばならないことが分かる。結局、八世紀の「 皇民」勅語が二十世紀の政策制定者によって採用された当初、血税を払うべき兵力動員を 要求しようとする最終目標がすでに含まれていたといえよう。

1 青木和夫ほか校注『続日本紀五』(岩波書店, 1998), p.272。

2 『教育栜語謹話』(直霊, 1943), p.20.

3 「「大東亜共栄圏」の台湾作家一「皇民文学」のかたち・陳火泉」(『野草』第46号, 1990.8). 


\section{3 万葉歌の政治利用}

「皇民」意識を昂揚させるためには、どうすればよいのだろうか。一対策として打ち 出されたのは、『万葉集』から皇民性のある古歌を見出して、その考え方を被支配者に植 えつけることであろう。これについて、山崎馨はは「万葉集もまた、一部の歌が昭和の軍 国主義に利用されるところとなり」と道破したうえ、そのうち万葉集の歌「御民われ」海民 行かば」および「今日よりは」の三首を取り上げている。それを参考にして管見を述べる と、1931 1945年の間に政治的に996歌・4094歌・4373歌の万葉三首を利用すれば、台湾 人を動員に応じる「皇民」へと脱皮させ易くなるだろうということである。

まず、996歌「御民吾 生有驗在 天地之 榮時尔 相樂念者」は「皇民」短歌の古例として 利用されていた。『万葉集』の本文には「皇民」の字面は一つもない。にもかかわらず、な ぜ996歌は「皇民」短歌代表作と追認されているのだろうか。それを可能にしたのは訓読 の回路にほかならない。そのために、三つの論拠があるだろう。

一つ目は、記紀冒頭の神名について本居宣長 ${ }^{5}$ が付けた注釈である。それによると、 「皇てふ㦒多し」と説明している。注目に值するのは、接頭語「皇」の用法である。二つ 目は、亡き天武天皇のために持統天皇の詠んだ挽歌(162歌)の原文に「高照 日之皇子」と 「高照 日之御子」という二節がある。佐竹昭広(他著)『万葉集 本文篇』を見ると、「皇子」 「御子」とも「みこ」というルビが付けてある。佐竹昭広(他著)『万葉集訳文篇』を見て も、「皇子」が「御子」に翻訳されている。即ち、原文のレベルとして持統天皇はすでに 「皇子」=「御子」の関係性を示唆しており、訓読のレベルとして学者は二つの単語を同一 視している。翻訳のレベルに至っても「御子」で統一表記されているのである。三つ目 は、「御民」について、「「み民」は御」の字が書かれてるるやうに、尊称の接頭語として 用みられ、「皇民」の如き意である」という澤潟久孝の注 ${ }^{8}$ がある。接辞・歌言葉・注釈の 成果を参考にしたら、「御民吾」二皇民吾」という同義関係が導き出しうるだろう。

実際、その一例は台湾三成協会の刊行した旬刊に加藤武雄の「皇民我生けるしるしあ り」 ${ }^{9}$ という標題に現われている。台湾読者の眼前に、996歌が「皇民」短歌として躍り出 たのである。もう一例は、996歌を鑑賞した齋藤瀏による「実に御民吾とは、皇民吾ん誇り であり」 ${ }^{10}$ という書き方である。日本内地の読書市場で996「皇民」歌が市民権を得ていた といえよう。

\footnotetext{
4 山崎馨「万葉集歌三首贅注」(犬養孝博士古稀記念論集刊行委員会編『万葉・その後：犬養孝博士古稀記念論集』 東京：塙書房, 1980), p.232.

5 大野晋ほか編集校訂『本居宣長全集』第九巻(筑摩書房, 1968), p.129.

6 佐竹昭広(他著)『万葉集』本文篇(塙書房, 1998年補訂版), p.28.

7 佐竹昭広(他著)『葉藮』訳文篇(塙書房, 1972), p.32.

8『万葉集注釈巻第 1 (中央公論社, 1957), p.336.

9 加藤武雄の「皇民我生けるしるしあり」(『誠』第303号, 1938.2.20.).

10 齋藤瀏『万葉のこころ』(朝日新聞社, 1942), p.66.
} 
「皇民化運動」が勢いを増すにつれて、当然ながらマスコミにも影響を及ぼしてい く。その端的な一例は、「本社発行国語新聞を㲜民新聞と改題」『台湾日日新報』1942.2.13 朝刊)である。新聞紙名が「国語」から「皇民」に変更される事自体が、すでに「皇民化」の 具体化が済んでいることを意味する。その時に以下の説明が付け加えられている。

本社発行の国語新聞は二月十一日の紀元節を期して、『皇民新聞』と改題し『みたみ しんぶん』と称することになつた、島民も大君の大御宝であり世界に比類なき皇民で あり御民であるとの皇民意識を昂揚せんが為めこの改題となつたものである

社告のついでに、「替民」=「御民」という996歌の同訓同義語に関する機会教育が行な われたのである。

やがて、そうした動きは教育現場にも浸透していった。1943年に台中一中を卒業し た鄭埌耀の短歌 $「 「$ 登民われ」と台湾人も歌はされ武装の中学生演習場駆くる」 ${ }^{11}$ がある。「皇 民」短歌が軍事訓練の時に歌い継がれていったので、996歌は皇民意識をアップさせる役 割を果たしていたことが見て取れる。

次いで、今奉部与曽布の一字一音式仮名書きの原表記が「今日よりはかへり見なくて 大君の醜の御楯と出で立つ我は」 ${ }^{12}$ と読み下されている。訳文の過程で浮上した「御楯」 は、「御」=「皇」という公式に従えば「皇楯」という造語が獲得できるはずである。実際、 帝国在郷軍人会台湾支部が発行した雑誌を見ると、「帝国在郷軍人会創立三十周年記念式 典に於ける総務口演の要旨」 ${ }^{13} に 「$ 国策の鄉ふ所に順応し」、「戦友」と「我が家」という二誌 が新しく皇楯」に変更されることが伝えられている。東京の軍人会館図書部により、 1940年1月から「皇楯」誌が発行されたことが確かめられる。台湾の場合、「大渓皇楯隊 十八日に結成式」(『台湾日日新報』1941.9.5, 朝刊)に注目すべきである。「志願兵志願者の 予備訓練と更に一般に対する皇民錬成とを目的として有志が自発的に大渓皇楯隊結成を 計画」という記事からすれば、真の志願兵になれた台湾青年は紛れもなく「皇楯」といえ る。

このように、訓読みに支えられて御民＝皇民、御楯＝皇楯という異形同語の関係が 次々と確立されていった。996歌を利用すれば、「皇民」短歌が手に入る。これは人民の 自覚向上を錬成するための皇民化運動にとって好都合な万葉歌といえる。4373歌を利用 すれば、「皇楯」短歌が手に入る。その「可梆里見奈入互」(返り見なくて)は、4094歌の 「可戟里見波 勢自」(かへり見はせじ)と共通した決意が認められる。だから、4094歌の 「大皇乃 䍩尔許曽死米」(大君の辺にこそ死なめ) とともに宣伝すれば、昭和天皇のために 犠牲を厭わない兵士を錬成すべき皇民化運動にとって好都合な万葉歌といえる。

11 孤蓬万里編著『台湾万葉集』(集英社, 1994), pp.104-105.

12 注7, p.511.

13 記手不明「帝国在郷軍人会創立三十周年記念式典に於ける総務口演の要旨」(『南の鎮め』第171号, 1941.1). 


\section{4 台湾歌人の「皇民化」献策}

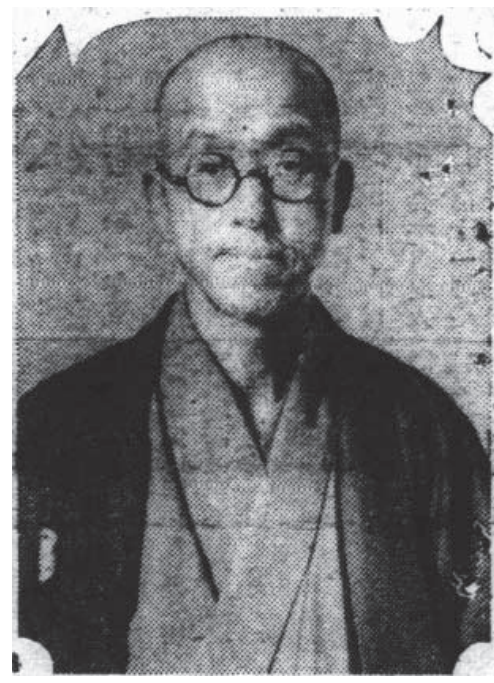

【図1】鎌田正威 ${ }^{14}$

台湾における「皇民化」の最初の用例について は、従来、歴史研究側から指摘がなされてき た。蔡錦堂 ${ }^{15}$ 「1936年8月4日」説が知られる。 それに対して、筆者は博士論文 ${ }^{16}$ で「1935年に「ス メラミタミ化」「皇民化」が短歌結社「八雲」系に主 張されていた」ことを指摘して、旧説を乗り越え た。ただ「皇民化」思想形成の一部始終を深く追求 する余裕はなかった。より徹底的に調査する前 に、「文官総督時代にその対台湾人抑圧の手める さ、コロン特権保護の不十分さをかこって蚌動 していた在台日本人ファッショ分子の待望した 武官総督のもとであの「皇民化」運動があれくる うこととなる」 ${ }^{17}$ という見通し方は有益だが、惜 しむらくは主唱者が誰なのかまだ提示されてい ないことだ。

管見によると、その提案者として台湾歌人鎌田正威を挙げるべきだろう。

1935年11月22日に行なわれた市街庄会議総選挙を阻止すべく、土屋米吉『台湾第一回 選舉の考察』18 によると、「皇紀二五九四年十一月十日」付で、「鎌田正威氏、土屋米吉氏」 らが「地方自治制改正反対運動建白書」を岡田総理大臣に送り届けた、という。その趣旨 は、次の通りである。

(1)「我々島民八国防上ノ立場ヨリ台湾総督ノ現在ノ態度二八反対スル者二御座候(略)台湾 統治ノ第一目的八漢民族习皇民化スルコトト存シ候」

(2)「台湾統治ノ指導精神 皇民化主義卜シ自治主義习撤廃スル事」

(3)「母国人二テモ先住民以下タル者モ数多キヨ認ムレト(略) 昨今ノ台湾二於テ八経済力 ノ退化(略)遂二八母国人ノ湾化习要求スル実情二有之候(略)先住民ヨシテ皇民化スル 事二一路猛進スヘキト存シ候」

そのうち、（1）の論調は国防の立場から「皇民化をを進めるべきとして参政権を本島人 に付与する文官総督の姿勢を批判している。（2）も「皇民化主義」を持ち出して文官総督の

14「神道の精神に基く維新社を創設する二年間東京で精進の鎌田正威氏が此の程帰台」(『台湾日日新報』 1933.10.18, 朝刊)

15「再論「皇民化運動」(『淡江史学』第18号, 2007.9).

16 頼衍宏『日本語時代の台湾短歌——結社を中心にした資料研究』(東京大学, 2008), p.279.

17 若林正丈「大正デモクラシーと台湾議会設置請願運動」(春山明哲ほか編『日本植民地主義の政治的展開：そ の統治体制と台湾の民族運動 一八九五一九三四年』東京：アジア政経学会, 1980), p.229.

18 土屋米吉『台湾第一回選舉の考察』(普泉社, 1936第二版), pp.274-278, p.283. 
自治主義を非難している。(3)は経済的に劣勢へと転落しつつある日本人が台湾化される 危機に劦かされるため、「皇民化をを急ピッチで着手すべきだという献言である。再三再 四「皇民化」を繰り返しているこの1934年の建白書こそ、現存する文献上における「皇民 化」の初出だったといえよう。

「皇民化」の由来と展開を解明する際、鎌田正威(1885～1935年)の経歴からアプローチ すべきであろう。その墓誌銘 ${ }^{19}(1936$ 年) は以下のとおりである。

菄京帝国大学 7 卒業直二台湾総督府二奉職(略)特二総督明石将軍二秘書官タルヤ熱 誠献替重望 7 荷フ此間数次海外二遊七私費 $コ$ 投シ危難 7 冒シテ各地ノ文物制度 7 探究 シ貢献スル所多シ官 ヨ辞シ(略)多年) 宿望タル神道, 研究二専念シ 台湾維新社及皇政会 7 創設惟神大道) 宣揚卜日本精神) 作興卜ニ全力 7 傾尽又(下略)

（下線は筆者による。以下同じ）

まず、(A)に関しては東大在学中「筧克彦先生の高弟でしたから、神道に関する研究

は、相当に進んで居られた」 ${ }^{20}$ と偲ばれている。筧克彦 ${ }^{21}$ の著作を調べると、「神人合

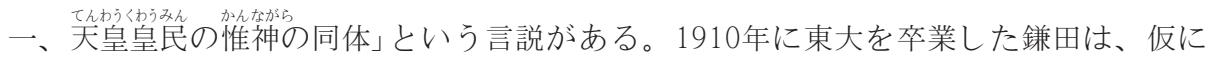
学生時代からでない場合でも、「台北帝大で特殊講義を開講中」のため恩師が渡台した際 に「筧博士歓迎会 門下生の催し」(『台湾日日新報』1930.1.11，朝刊）という活動に参加して いれば、その「皇民」説の薫陶を受けることができたはずである。

それと関連する $(\mathrm{C})$ は、「世界を週遊して 日本の皇室中心主義と日本人の特性が 世 界で卓越して居る事を知つた一鎌田正威氏談」(『台湾日日新報』1927.7.1夕刊)という記事 から確かめられる。それによると、「吾々日本人の自覚せね柿ならぬとは日本民族は 其皇室中心主義の惟神道を拡充し(略)神人帰一して(略)皇民として必ずその実現に精進す べきである」と報じられている。換言すれば、海外を視察した後、「皇民」として惟神道 を実行に移す意欲を示している。筧恩師の理論を忠実に導入する意気込みが観取でき る。

(B)の職歴を経て、鎌田は明石総督を「英雄」22視するようになった。また、『台湾総督 明石大将言行録』編集計画を立ち上げたので、それに関連する文献資料を提供するよう、

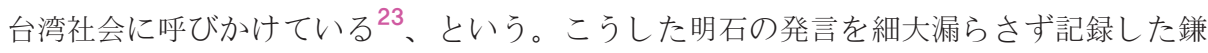

19 陳恵芳「流落巷弄的石碑一鎌田正威墓誌」(『国史館臺灣文献館電子報』第185号, 2019.8).

20 太田秀穂「鎌田氏観」(佐々波外七編『鎌田正威先生追想録」第一輯, 台湾維新社, 1936), p.161。

21『風俗習慣と神ながらの実修』(春陽堂書店，1939普及版），p.75.なお、「此の小冊子は大正五年一月より三月 に至るまで、某所に於て毎週一時間宛七回になしたる講話の速記なり」(p.1) とあるので、1916年の発言 だったことが分かる。

22 「明石総督の偉らさ 明石総督秘書官だつた 鎌田正威氏の話」(『台湾日日新報』1929.8.26, 朝刊)

23 「編纂明石総督言行録」 『台湾日日新報』1924.7.11, 朝刊). 原文：「鎌田正威氏。以元為明石総督秘書官関係。 欲乗此時。編纂台湾総督明石大将言行録。以資感化。藉垂入遠。現正捜羅材料(略)欲寄贈材料者。宜至是日 為止」 
田の協力のもと、小森徳治『明石元二郎』上巻 -下巻(台北：台湾日日新報社, 1928)の出版 が成立した。同書を調查したところ、「皇民化」の用語に近い言説として二つの看過でき ない箇所がある。

〈1〉親友杉山茂丸氏の進言」：「台湾三百万新附の民(略)を帝国皇化の民とせらる〉を総督 政治の第一急務として、歴代の総督は朝命を蒙られた訳でムい升 ${ }^{24}$

〈2〉新任最初の訓示」「総督の眼中には、同化不同化は問題でなく、何うあつても同化 杼ばならぬ。而かも異種族の同化は日本古来の国是である ${ }^{25}$

明石総督が赴任する前の「皇化」と就任した後の「同化」は、まだ「皇民化」という熟語に なっていない。ところが、〈2〉を引用したと思しき土屋米吉『台湾第一回選挙の考察』 26 の次の一節を見ると、不思議にも「皇民化」が顕れてくる。

この点明石将軍はその訓辞の中に「最近同化政策ヨ疑フモノカアルカソ八大キナ ル誤リナリ。吾等八一人モ残サス台湾在住民ヨスメラミタミ化导ネハナラヌ」と述べ てるるが、

即ち、明石総督の「同化じねばならぬ」という意を述べているうちに、土屋によって 「スメラミタミ化异ネハナラヌ」と置き換えられてしまったわけである。もう一度土屋 『台湾第一回選挙の考察』 ${ }^{27}$ 「スメラミタミ化」皇民化」という主張を吟味すると、明ら かに「皇御民化」が「皇民化」と言い換えられている。要するに、明石総督の言行に仮託 しつつ「同」を「皇民」に置換する操作を経て初めて「皇民化」という単語が成立したものと 思われる。その文献操作を承知したうえで、土屋とともに1934年の建白書に鎌田が署名 し、首相に送付したところ、「皇民化」という用語が中央政府も共有するようになったの ではないだろうか。

それに先立ち、鎌田正威が晚年総裁として活躍した「皇政会では数年来武官総督実現 運動を開始し奮闘して来た」が「昭和八年十月」に「武官総督要請の建白書を中央要路に送 り、当時は重大問題として当局の忌諱にふれ同志等は検束せられ、暴圧を加へられたる」 ${ }^{28}$ と回顧されている。捕まった一人に、「土屋君も亦た検束された」 ${ }^{29}$ と想起されている。 この1933年の建白書において、先の武官総督の「皇民化」という遺志を盾にしたかどうか 不明だが、実際、土屋米吉は文官総督更迭論のせいで一時的に人身の自由を失ってし まった。彼にとって、土屋米吉「大阪天神橋ホテルに催したる鎌田正威先生告別式場に 於ける韦辞」によると、彼にとって、「僕に実子にまさる愛を賜ひ」「恩師鎌田正威先生」 30

24 小森徳治『明石元二郎』下巻(台湾日日新報社, 1928), pp.29-30.

25 小森徳治『明石元二郎』下巻(台湾日日新報社, 1928), pp. $50-51$.

26 注 18, p. 38 .

27 注 18, pp.7-8.

28 皇政会の運動に就て」(皇政宣揚会編『真の叫」, 皇政宣揚会, 1936), p.3

29 永山幹事「開会の辞」(皇政宣揚会編『真の叫』, 皇政宣揚会, 1936), p.52. 


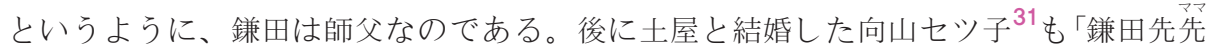
を偲び奉りて」を題にして「しま人のすめらみたみとなりぬべき日をこそ祈れみたまの まへに」を詠んでいる。これは「台湾人の皇民化すべき」心を訴えた最初の皇民化短歌と

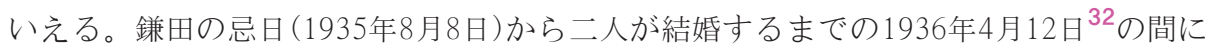
成立したものである。

(D)については、鎌田の遺志を継いだ台湾維新社の森政禧だが、その「祭詞」に「台湾 五百万同胞の絶対的皇民化」33を訴え、皇政宣揚会代表である山下好太郎も「祭辞」で「島民 の皇民化」 ${ }^{34}$ を強調している。亡き鎌田の霊が安心できるように「皇民化」運動の成功の ために捧げる決意を示しているわけである。墓誌銘に「皇民化」の一語をも刻まずに行間 に尽くその運動を産み出す文脈を得たといえよう。

鎌田の枠組みを忖度すれば、筧恩師の惟神道を実践しているうちに、その「いしん」 の発音に因んで台湾維新社を創立した。また、理念が認められて皇政宣揚会にも総裁と して迎えられた。台湾人をして「一視同仁の皇化に浴せしめん」と「只管島情の研究に没

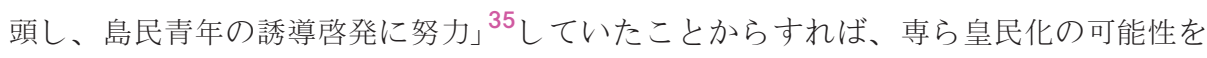
色々と探って研究を続けていたらしい。その生存中、「啓蒙運動に従はれた」と皇さされる とおりに、皇民化の啓蒙運動期と位置づけられる。その成果として見過ごせないのは、 「台湾に於ける社会事業団体である○○会に建議された草案」37であろう。それによる と、1933年11月から「惟神之大道による神扯の修行を」経て、「既に同化の可能性と神拝 の効果の顕著なることを証明せられたりとすれば(略)、台湾には同化の道は早や既に開 かれたり」としている。その過程で、鎌田は「ミソギ修行」を通じて「本島人を精神的に導 いて行く」と述べ、「土屋(略)が助手として右修行に手伝ふ」 ${ }^{38}$ という。つまり、鎌田が 率先して台湾人同化の成功例を作り出した側で、土屋米吉を右腕と頼んだのである。

しかし、1936年9月に待望の武官小林総督が着任するのを俟たず、鎌田は1935年8月 に他界した。本格的な皇民化政策期を迎えるためには、その精神を継承した有志家の奔 走が必要である。武官総督が実現した翌月、注目に值するのは皇政宣揚会(編)『真の 叫』39の出版である。その中に、「小林総督への建白内容」が揭げられている。具体的に は「台湾統治二関スル建白書」だが、「本島統治ノ根源タル島民ノ皇民化卜本島防衛ノ見地

\footnotetext{
30 太田秀穂「鎌田氏観」(佐々波外七編『鎌田正威先生追想録』第一輯, 台湾維新社, 1936), pp.266-267. 31 太田秀穂「鎌田氏観」(佐々波外七編『鎌田正威先生追想録』第一輯, 台湾維新社, 1936), p.290。

$32\ulcorner 土$ 屋米吉君結婚」(『台湾日日新報』1936.4.13, 朝刊)。

33 編著者不明『奧津城建設報告書』(鎌田正威先生墓碑建築事務所, 1936), p.29.

34 編著者不明『奧津城建設報告書』(鎌田正威先生墓碑建築事務所, 1936), p.27.

35 法水了禅「噫鎌田正威先生」(佐々波外七編『鎌田正威先生追想録』第一輯, 台湾維新社, 1936), p.109.

36 太田秀穂「鎌田氏観」(佐々波外七編『鎌田正威先生追想録』第一輯, 台湾維新社, 1936), p.161。

37 亭々生「遷り行く世相を眺めて」(佐々波外七編『鎌田正威先生追想録』第一輯, 台湾維新社, 1936), pp.145-147.

38「本島人十名が神のミソギ修行 鎌田正威氏に導かれ 三日間北投無名庵で」(『台湾日日新報』1933.11.6, 朝刊).

39 「皇政会の運動に就て」(皇政宣揚会編『真の叫』皇政宣揚会, 1936), pp.4-5.
} 
ヨリ我等母国人ガ総テノ中枢タルヨ要スルハ言习俟タス」という、内地人を優位に据え つつ台湾人を皇民化すべきという理念が開陳されている。また、「島民皇民化ノ施設徹 底」として「新聞紙及其他刊行物ノ漢文习禁止スルコト」などが列挙されている。そし て、「総督は之が建白理由を聴取することとなり」 ${ }^{40}$ とも伝えられている。やがて、請願 どおりに、新聞の漢文欄 ${ }^{41}$ が廃され、小林総督も「島民の皇民化」をはじめとする「台湾統 治方針」42をメディアに公言している。

兵力動員に限っていえば、小林総督の消息によると「昭和八年頃に本島人の皇民化促 進の方法として優秀な本島人青年を志願兵として軍隊に入れてはとの意見が府内にあつ て、之を台湾軍並に中央軍部に致し研究を願つたと云ふ事もあるさうだ」43という。そ れを信じるなら、1933年に中川総督と軍部の間に「皇民化の公文書の往復があった。小 林総督も「同様な考へから台湾軍及陸軍中央部と話し合つた事もある」として興味津々で ある。しかし、結局その在任中「軍夫」をはじめとする「準戦時動員体制の基盤が形成さ れていた」奋にすぎない。それに対して不満を抱いたのは皇政会である。「外地徴兵令実 施に就き代表山下好太郎(略)を上京せしめ二十四日午前十時より首相、陸相、海相、拓 相、企画院総裁を歴訪、左記建白書を手交陳情した」 ${ }^{45}$ と報じられるように、皇政会は台 湾人の国民皆兵政策を遊説すべく第一線に乗り出した主唱者である。やがて、1942年に 募兵制、1945年に徴兵制が実現するようになった。表1のように、歴代総督の施政はま すます皆兵制を旨とする「皇民」の本義に合致しつつある。もし鎌田に霊があって1945年 の成果を眺めたら、愁眉を開けるのではないだろらか。

【表1】皇民化運動三段階

\begin{tabular}{|c|c|c|c|c|}
\hline 形態 & 「部報」 ${ }^{46}$ の分類 & 「国民皆兵」の原義 & 実施年 & 皆兵との距離 \\
\hline 軍夫召集 & 第一歩の前の準備段階 & $\begin{array}{l}\text { 正式の兵ではないが、 } \\
\text { それに近い }\end{array}$ & 1937 & $\triangle$ \\
\hline $\begin{array}{l}\text { 志願兵制度 } \\
\text { 施行 }\end{array}$ & \begin{tabular}{|l|} 
「六百万島民は真に名実共皇民た \\
るの第一歩を画するに至つた」
\end{tabular} & $\begin{array}{l}\text { 正式の兵籍があるが、ま } \\
\text { だ少数に限られている }\end{array}$ & 1942 & 0 \\
\hline $\begin{array}{l}\text { 徵兵制度 } \\
\text { 施行 }\end{array}$ & $\begin{array}{l}\text { 六百万島民は真に名実共皇民た } \\
\text { るの第二歩 }\end{array}$ & $\begin{array}{l}\text { 全面的に兵籍が与えられ } \\
\text { る }\end{array}$ & 1945 & (C) \\
\hline
\end{tabular}

40 「建白理由を総督に説明 皇政会代表が」(『台湾日日新報』1936.11.16, 朝刊)．

41 「漢文欄の廃止に就いて 島内四日刊紙の申合」(『台湾日日新報』1937.3.1, 朝刊).

42「台湾工業化に全力 南支開発も計画 昨夜入京 小林総督語る」(『朝日新聞』1939.5.20, 朝刊).

43 「皇民化が徹底すれば識者は黙つて居まい台湾の志願兵制度につき小林総督が記者団に語る」(『台湾日日新 報』1938.1.23, 朝刊)

44 檜山幸夫「近代天皇制国家の台湾統治——台湾人戦死者の靖国神社合祀問題を事例に」(李玉瑾編『近代東亜中 的台湾国際学術研討会論文集』新北：台湾図書館, 2013), p.184.

45「外地徵兵令の実施を建白皇政会代表各省を訪問陳情」『台湾日日新報』1941.7.25, 朝刊).

46 文教局社会課「大君の御楯とならむ 勤行報国青年隊 志願兵制実施を控へ 皇民鍊成に一路邁進」『部報』第 132号, 1941.10.15). 


\section{5 戦犯の遺詠}

「虎尾鎮公所勧導 民間祖先牌位上 除去「皇民」字様」 47 という記事からすれば、祭祀の 現場における「皇民」の字面は1960年代までは残っていたと見える。すると、皇民短歌は 果たして1945年8月15日以降完全に姿を消したのだろうか。巣鴨遺書編纂会(編)『世紀の 遺書』48の「戦犯死攻者名簿」には台湾出身者 24 名がリストアップされている。揭載され た九通の遺書を一読すると、定型の短歌を残した二名の遺詠を見出し得る。

まず、1946年8月30日に濠洲ラバゥルで処刑された台中出身の元陸軍軍属林江山(日本 名：林義徳)の次の辞世短歌 49 を検討しよう。

御国に捧げまつらん若桜こっ「ラバゥル」に今先只散り行く

謡曲「賀茂」における「卸国」50のルビに従えば、初句は五音からなるため、一首は定 型のとおりである。森岡清美によると、「遺書や辞世の場合、文例があったり(略)軍隊

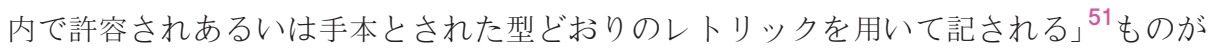
あるという。もし林の歌に手本があったとすれば、どのような文献だろうか。管見に よると、「靖国の英霊に捧ぐ能「忠霊」」(『朝日新聞』1941.11.12. 夕刊) と報じられた「忠霊」 に留意すべきである。謡本 ${ }^{52}$ の一部と比較してみよう。

・上歌：自づから春の手向の桜花。

・ワキ：(略)花と散りにし忠霊の御心如何におはすらん。

・地：その上靖国と斎はれて、御代万代に動ぎなく。(略)今は哭令満足た $゙$ 有難 き極みなり。

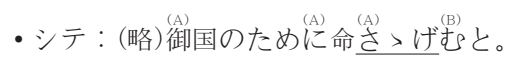

見ての通り、(a)は(A)の動詞句と一致しており、(b)の「ん」は(B)の「む」を口語化し た結果である。また、植物十副詞+動詞という修飾構造もほぼ同様である。したがって、 一首は謡曲をもとに創作したものといえる。刑死された後、林も「忠霊」として仰がれた いとする気持ちが伝わってくる。

なお、上句の動詞用法については、「勝ちぬく誓」53における「みたみわれ大君にすべ

\footnotetext{
47 『民声日報』1962.4.14, 朝刊.

48 巣鴨遺書編纂会(編)『世紀の遺書』(巣鴨遺書編纂会刊行事務所, 1954第四版), pp.53-54.

49 巣鴨遺書編纂会(編)『世紀の遺書』(巣鴨遺書編纂会刊行事務所, 1954第四版), p.545.

50 小山弘志ほか校注・訳『謡曲集1』(小学館, 1997), p.62.

51 森岡清美「研究資料としての戦没者の既刊手記」(『淑徳大学研究紀要』第29号, 1995.3).

52 「附録」菱刈隆『忠霊塔物語』(童話春秋社, 1942), pp.262-265.

53『台湾産業組合時報』第13号, 1943.10.
} 
てを捧げまつらん」と全く同じである。ゆえに、林の遺詠は「皇民」を称揚する「勝ちぬく 誓」と、皇楯が君国のために犠牲になった「英霊」を顕彰する時局能『忠霊』を同時に引用 して成立したものと観取できる。

次いで、1948年6月22日にジャワのグロドックで処刑された高雄出身の元陸軍軍属董

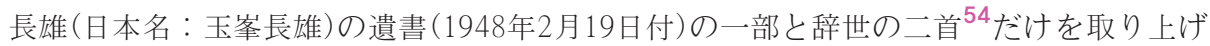
よう。

・D前略一本職八台湾人デアル。(略)ソシテ国家ノ所属ガ変ツテモ、本職八日本 軍人トシテ死ンデ行キ度イノデアル。(略)最後ノ御願ヒ二将来大日本帝国ガ復 興セバ、ドウカ本職ノ一子董英明 政府二於テ日本教育 7 恵ミ給ハラン事习御 願ヒ申シ上ゲマス。

・惜まれて吉野の花の散る如く散らましものをますらを吾は

・たわけ奴の擊つ十発は男の子吾が胸板貫くも点ことは貫けじ

遺書を検討する際に、陳火泉「道」における稚月女 ${ }^{55}$ の皇民への道といふは、死ぬこ とと見附けたり」を吟味すべきである。それは江戸時代の代表的な武士道論書『葉隠』56 の「武士道と云は、死ぬ事と見付たり」を引用した結果だと指摘したい。その武士道の死 生観を持つ「皇民の道」の定義に従えば、董が表明した「日本軍人トシテ死ンデ行キ度イ」 という決心はすでに「皇民」兼「武士」である気魄を示しているといえよう。

短歌のほうも、武士の文脈をぬきにしては、その境地は語れない。第一首の場合、「ま すらを」という和語がある。鹿持雅澄『万葉集古義第 3 巻』 ${ }^{57}$ の翌士趾士という訓読法に則る と「武士」という董の自己認識が確かめられる。また、それ以外の歌語の詠み方を見て も、『葉隠』58を見過ごせない。それによると、「吉野の花見」という記述と中野圭之助の 扇歌「鿖しまる>時ちりてこそ世の中の花も花なれ人も人なれ」がある。第一首と較べる と、「吉野の花」にとどまらず、(a) (b) (c) もそれぞれ (A) (B) (C)を踏襲していると指摘し たい。ならば、(c)の「散」といら動詞の反復法も (B) と「人」との同語反復に触発されて成 り立った可能性がある。歌心を見ると、花も人も惜しまれて散るべしとする扇歌に対し て、花に喻えた武士も惜しまれて散ればよいのだという希望を託する董歌がある。言葉 の引用と比喻・反復修辞法からすれば、董歌は扇歌を本歌取したものだといわざるをえ ない。

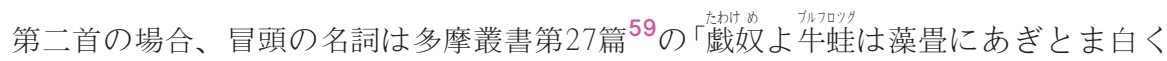

54 宩鴨遺書編纂会(編)『世紀の遺書』(巣鴨遺書編纂会刊行事務所, 1954第四版), pp.738-739.

55『文芸台湾』第6会-第3号, 1943.7.

56 相良亨ほか校注『三河物語 葉隐』(岩波書店, 1974), p.220.

57 鹿持雅澄『葉集古義』第3巻(吉川半七, 1898), p.123.

58 相良亭ほか校注『三河物語 葉隱』(岩波書店, 1974), pp.342-349.

59 泉甲二『白き秋：歌集』(研究社, 1947), p.164. 
鳴き響みつつ」と共通している。そのため、多磨短歌会の主宰者から調査すべきであ る。「特殊潜航艇のことを聞きて」 ${ }^{60}$ を題とする北原白秋の第 3 首「わき知らに人の胸板 号つものはただにひたぶるのまことなるなり」と比べると、名詞(e) (f)の対照と動詞 (d) は (E) (F) (D) と一致している。「九軍神」の散華を謳歌する白秋の肉体的な (E) および精神 的な $(\mathrm{F})$ からなる構造をそのまま導入した結果、董の歌が出来たと思わ机る。軍神とし て散りたいとする董の気持ちが理解できる。そうした軍神を褒め称える軍歌として、「闘 魂燃ゆる「必勝歌」二度目の国民愛国歌決る」(「朝日新聞」1944年12月22日)が想起できる。 その第一段に、「今日よりはかへりみなくて大君のしこの御楯といでたつ我はああ防人 の昔よりみたみ我等の雄心は」とあり、第二段に「天皇の御楯と誓子真心は留めおかまし いのち死ぬともああ陸海に大空に高く雄叫ぶ軍神の後にぞ続く我等また」とある。第一 段の場合、下線部は4373歌、波線部は996歌を引用する万葉の政治利用態勢が見える。第 二段の場合、「皇楯」=「軍神」という描き方が認められる。白秋の軍神短歌を踏襲したか らには、董も真個の皇楯といわざるをえない。

なお、比喻法に関しては林の「桜」と董の「花」を合わせると、桜花である。馬場豊二 『皇民練成弓道指導書』 61 の武士道と桜」という章のもと、「他の花の如く幾日も梢に執着 してるるのと異つて、我国民より愛賞されてるる点も、此処にあるので、武士は精神的 に冥合し、花は桜木、人は武士と呼ばれるに至つた」という説明がある。二面の皇楯と 化した両人の遺詠は、結局武士道の風合いを持たせたものと位置づけられよう。

\section{6 日本人の憶念と台湾人の反省}

鎌田正威の墓誌銘について補足すると、短歌結社「八雲会」の経歴を記入すべきであ る。なぜなら、主宰者である井上孚麿の「敷島の道は、皇国の、すめらみ民としてのま ことの心を歌ひあげべき」62という理念のもと、「皇民」の真誠を短歌で示すべく、鎌田 正威と土屋米吉と向山セツ子らが馳せ参じて出詠していたからである。鎌田の場合、「島 の民も岐美二柱のす急なれば践ませざらめや神のまみちを」 ${ }^{63}$ という歌がある。台湾人 も造化二神の末裔なので神の真道を践ませないだろうか、そんなことはしないとい う。これは注38で既述した、皇民化運動啓蒙期において惟神道の裙を台湾人に体験させ たうえで同化の成功例を詠んだものにほかならない。また、市川清一郎「鎌田正威君の 追懷記」64における「大君のみたてとならむ願もてとこよべにても猶いのれ君」という歌 から鎌田の宿願は「皇楯」たらんとすることが見える。そのような皇民化初期の実績と

\footnotetext{
60 北原白秋『牡丹の木』(河出書房, 1943), pp.209-210.

61 馬場豊二『皇民練成弓道指導書』(明治図書, 1941), pp.176-177.

62 乙守たまを「敷島の道をさぐりて」(佐々波外七編『鎌田正威先生追想録』第一輯, 台湾維新社, 1936), p.140.

63 乙守玉緒編『八雲集』(八雲会, 1937), p.27.

64 市川清一郎「鎌田正威君の追懐記」(佐々波外七編『鎌田正威先生追想録』第一輯, 台湾維新社, 1936), p.71.
} 
「皇楯」の素志を持ったのに急逝してしまった鎌田の霊前に、土屋と結婚した向山が最初 の皇民化短歌を発表したのは先述したとおりである。

では、皇民短歌を育む土壤を提供した主宰の場合はどうだろうか。1933年12月23日 に生れた皇太子殿下に捧げる井上孚麿 ${ }^{65}$ の祝歌「たかひかるあまつひつぎのみひかりに ひかりそひゆくみたみわれらも」がある。結句は『万葉集』996歌の「皇民我」を踏まえて いると指摘できる。皇室の慶事を祝賀するために台湾日日新報が和歌漢詩を公募したと ころ、日本人や台湾人や朝鮮人なども作品を投稿した。和歌の部の撰者役を務めた井上 孚黁66の1935年の短歌だが、「賀状の返しに未見の本島人少年に」と題した中に「かくば かりたふとき歌を詠み出でし君はまことのすめらみ民ぞ」という一首がある。台湾人出 詠者を「真の皇御民」と賞賛しているわけである。戦後になっても、井上は依然として信 念を変えようとしなかった。なぜなら、「台湾人」を「同胞」と見做したうえで、「領土は も他国ともなれみ民はもとはのみたみとわれは信ずる」 ${ }^{67}$ と詠んでおり、旧植民地の「皇 民」を「永久の皇民」と定義づけているからである。靖国神社に入祠された董長雄のごと き亡き「皇楯」を慰めるための称呼だけならともかく、敗戦の苦難を乗り越えた後、生き 残った元皇民・元皇楯までも「永久の皇民」と思い込んでいるわけである。

その台湾人永遠皇民論を唱える作を含む歌集の件で躊躇った井上のために、尅建堂

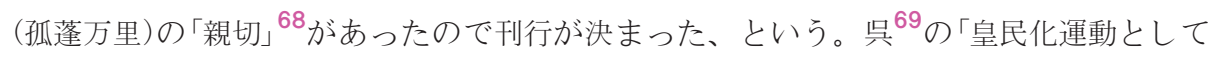
改姓名許されたるは昭和十六年」と「高校の卒業証書は日本名大田建太郎学者の如し」とい ら歌からすれば、彼は「皇民」政策支持者だったと見て取れる。また、「台北市日治時代 在郷軍人編組名冊」 ${ }^{70}$ というリストにも「呉建堂」が入っている。日本の軍籍を授けられ た以上、「皇楯」だったともいえる。しかし、呉建堂『孤蓬万里半世紀』の「人権を重んず る見地から、植民地は将来再びあってはならぬものであり、今更日本の植民政策を云々 しても仕様がない」 ${ }^{71}$ という主張に従えば、戦後の咫は皇民化運動を含む植民地支配を非 難するようになった。その遣主宰の考え方と同調するように、皇民を批判する短歌が現 われた。

例えば、1978年11月の歌会に蔡松濤「御民われ活けるしるしなどなかりけり無茶なる 戦さ足かけ九年」 ${ }^{72}$ がある。『万葉集』996歌を本歌取しつつ、元来の皇民肯定論を否定論 に改める創意が認められる。敗戦と日中国交正常化のせいで、日本が台湾をいわば二連 捨した事実に鑑みても、本歌取の逆用が諒解されるであろう。戒䇯令が解除された後、

\footnotetext{
65『続雲のゆきかひ』(井上孚麿先生歌集刊行会, 1980), p.167.

66『続雲のゆきかひ』(井上孚麿先生歌集刊行会, 1980), p.224.

67『続雲のゆきかひ、井上孚麿先生歌集刊行会, 1980), p.277. 井上孚麿『望南集』(青々会出版部, 1972).

68「はしがき」『続雲のゆきかひ』(井上孚麿先生歌集刊行会, 1980), p.3.

69 孤蓬万里編著『孤蓬万里半世紀』(集英社, 1997), p. 80.

70 黄漢夫. 1948年11月30日. 台胞被日本徵服兵役案. 国家発展委員会档案管理局. 2019年8月6日閲覧. 〈https://aa.archives.gov.tw/archivesData.aspx?SystemID=0000390872〉

71 吳建堂『孤蓬万里半世紀』(吳建堂, 1978), p.3.

72 御民われ活けるしるしなどなかりけり無茶なる戦さ足かけ九年」(『台北歌壇』第53号, 1979.2).
} 
游来乾 ${ }^{73}$ 「皇民化化け足らぬとて五十年後尚も短歌詠む芋つ子の馬鹿」もある。皇民化 の余燼といって戦後半世紀経っても創作活動を継続する台湾歌人に猛省を促す歌も登場 した。

なお、黄得龍 ${ }^{4}$ の「異族にて唄わされたり「大君の辺にこそ死なめ」まこと幻」と「大君 の辺にこそ死なめと召されども君高高と近寄り難し」がある。『万葉集』4094歌を批判的 に引用しつつ、傷疿を負った台湾人学徒兵として、いわば皇楯の実体験に基づいて歌詞 内容そのものの虚仮を告発するような力作も1990年代に発表された。

\section{7 おわりに}

以上のように、皇民化運動政策が形成された世相の背後には歌人達が関与していた。 鎌田正威を慰霊すべく発生した皇民化短歌だが、1948年の台湾人戦犯遺詠に皇民短歌の 下限が求められるはずである。戦後、台湾人を永遠の皇民と看做し続ける元台北帝大教 授の歌に対して、台湾人歌人は短歌をもって反撃したのである。

靖国神社第65回「みたままつり」ポスター(2011年7月)に「英霊(みたま)に感謝と祈り の夏祭」とある。それに従えば、異民族の台湾人を改造する皇民化運動は結局「皇民等(御

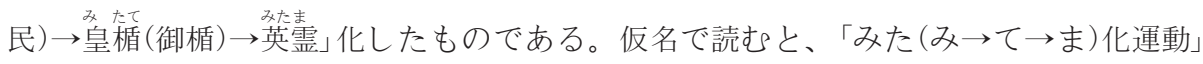
といえよう。漢字でいうと、「皇 (民一楯) 化運動」もしくは「御(民一楯 $\rightarrow$ 魂) 化運動」と略 称してもいい。

\footnotetext{
参考文献

山崎馨 (1980)「万葉集歌三首贅注」。養孝博士古稀記念論集刊行委員会編『万葉 ·その後：犬養孝博士古稀記念 論集』東京：塙書房, p.232. Yamazaki. Kaoru(1980) Manyosyu sansyu zeityu： Manyo sonogo ed. Inukai Takashi hakushi koki kinen ronshū Publication Committee, Tokyo : Hanawashobo, p.232. 井上孚麿(1980)『続雲のゆきかひ』(井上孚麿先生歌集刊行) Inoue, Takamaro(1980) Zoku Kumo no Yukikahi, Tokyo : Inouetakamaro Sensei Kashu Society.

皇政宣揚会編(1936)『真の叫』(皇政宣揚会). Koseisenyoukai(1936) Sin no Sakebi, Taipei：Koseisenyoukai. 孤蓬万里編著 (1994)『台湾万葉集』(集英社). Koho, Banr (1994) Taiwan Manyosyu, Tokyo：Shueisha. 蔡錦堂 (2007)「再論「皇民化運動」」『淡江史学」第18号, p.232. Tsai, Chin-tang(2007) Discourse Further Upon the Kōminka Movement, Tamkang History Review Vol.18, p.232.

佐々波外七編 (1936)『鎌田正威先生追想録 第一輯』(台湾維新社). Sazanami, Toshichi(1936) Kamada Seil sensei tsuisouroku, Taipei : Taiwan Ishinsya.

巣鴨遺書編纂会編(1954)『世紀の遺書』(鴨遺書編纂会刊行事務所, 第四版). Sugamo Isho Hensankai (1954) Seiki
}

73 二月台北歌会詠草」(『台北歌壇』第117号, 1995.5).

74 黄得龍『楖子の木』(自費出版, 1993), pp.82-213.初出：『新日本歌人』1990年2月と同1992年1月。 
no isho, Tokyo : Sugamo Isho Hensankai Kanko Jimusyo.

土屋米吉 (1936)『台湾第一回選舉の考察』(普泉社, 第二版). Tsuchiya. Yonekichi(1936) Taiwan dai ikkai senkyo no kōsatsu. Taipei : Fusensha.

若林正丈 (1980)「大正デモクラシーと台湾議会設置請願運動, 春山明哲ほか編『日本植民地主義の政治的展開 : その統治体制と台湾の民族運動 一八九五一九三四年』、東京：アジア政経学会，p.229. Wakabayashi, Masahiro(1980) Taisho-Democracy and The inaugurating national diet movement in colonial Taiwan : The Political development of Japanese colonialism ed. Haruyama, Meitetsu, Tokyo : JAAS, p.229.

編著者不明 (1936)『奧津城建設報告書』(鎌田正威先生墓碑建築事務所). Author unknown (1936) Okutsuki kensetsu hokokusho, Taipei : Kamada Seil sensei bohi kenchiku jimusho. 